\title{
Promosi Dan Penerapan Budaya Keselamatan Pasien
}

Sophia lumbanbatu

sophialumbanbatu@gmail.com

\section{Latar Belakang :}

Gerakan keselamatan pasien merupakan aplikasi dari adanya tekanan masyarakat, namun gerakan ini merupakan gerakan yang mengandung unsur moralitas dan kemanusiaan yang pada akhirnya menjadi suatu kewajiban. Organisasi rumah sakit sebagai pemberi pelayanan kesehatan harus mampu menerima keselamatan sebagai nilai baru dalam budaya organisasi dengan komitmen berani berubah, berubah dalam arti blaming cultur menjadi safety cultur (Cahyono, 2008). Dengan berlalunya waktu dan perkembangan ilmu pengetahuan dan teknologi rumah sakit tidak hanya menjadi tempat untuk menyelamatkan pasien. Berbagai layanan dapat diakses oleh pasien yang membutuhkan bantuan. Pasien yang memerlukan bantuan menyeluruh dan intensif selama 24 jam dapat mengakses layanan rawat inap. Keselamatan pasien di rumah sakit melibatkan partisipasi dari semua petugas kesehatan, terutama perawat. Perawat sebagai salah satu tenaga kesehatan yang mempunyai jumlah cukup dominan di rumah sakit yaitu sebesar 50 sampai $60 \%$ dari jumlah tenaga kesehatan yang ada. keselamatan adalah output dari individu dan kelompok terhadap nilai-nilai, sikap, kompetensi, dan pola dan kebiasaan yang mencerminkan komitmen dan gaya dan kemampuan organisasi dan manajemen keselamatan kesehatan. Budaya keselamatan pasien merupakan suatu hal yang pentingkarena membangun budaya keselamatan pasien merupakan suatu cara untukmembangun program keselamatan pasien secara keseluruhan, karena apabila kita lebih fokus pada budaya keselamatan pasien maka akan lebih menghasilkan hasil keselamatan yang lebih apabila dibandingkan hanya menfokuskan pada programnya saja. Teori Reason menyatakan bahwa insiden keselamatan pasien disebabkan oleh dua faktor, kesalahan laten dan kesalahan aktif. Kesalahan laten terkait dengan insiden keselamatan pasien meliputi lingkungan eksternal, manajemen, lingkungan sosial atau organisasi, lingkungan fisik, interaksi antara manusia dan sistem. Budaya keselamatan adalah bagian dari kesalahan laten yang terkait dengan manajemen, sedangkan indikator budaya keselamatan meliputi 
kerja sama, komunikasi, kepemimpinan, pelaporan dan respon terhadap kesalahan tidak menghukum. Kunci pencegahan cedera dalam pelayanan keperawatan adalah identifikasi risiko. Hal ini sangat tergantung pada budaya kepercayaan, kejujuran, integritas, dan keterbukaan berkomunikasi dalam sistem asuhan keperawatan.

\section{Metode :}

Dalam penerapan kebudayaan keselamatan pasien dapat dilakukan dengan melakukan penelitian dibeberapa Rumah sakit dengan mengumpulkan hasildari jurnal yang telah diteliti oleh beberapa sumber yang telah didapatkan antaralain, metode Identifikasi pasien yang merupakan suatu upaya atau usaha yang dilakukan dalam sebuah pelayanan kesehatan sebagai suatu proses yang bersifat konsisten, prosedur yang memiliki kebijakan atau telah disepakati, diaplikasikan sepenuhnya, diikuti dan dipantau untuk mendapatkan data yang akan digunakan dalam meningkatkan proses identifikasi (Joint Commission International, 2007).Selain identifaksi pasien metode yang di gunakan merupakan Perilaku perawat dalam pelayanan kesehatan dipengaruhi oleh berbagai macam faktor yang berkontribusi terhadap terjadinya insiden keselamatan pasien, salah satunya menurut Safety Attitudes Questionnaire (SAQ) Sexton et al (2006) ada 6 domain yang di nilai yaitu; Team work climate, safety climate, kepuasan kerja, stres, persepsi manajemen, dan lingkungan kerja.

Hasil :

Budaya keselamatan pasien yang diharapkan di rumah sakit adalah budaya keselamatan positif yang ditandai dengan adanya alur informasi yang baik dan adanya proses komunikasi yang berkaitan dengan pembelajaran pada saat KTD, memiliki pemimpin yang komit dan eksekutif yang bertanggung jawab serta pendekatan untuk tidak menyalahkan dan tidak memberikan hukuman pada insiden yang dilaporkan. Budaya keselamatan pasien dikatakan berhasil apabila semua elemen yang ada di dalam rumah sakit menerapkan budaya keselamatan pasien dalam pekerjaannya sehari -hari. Budaya keselamatan merupakan bagian dari budaya organisasi dimana budaya 
keselamatan hal ini dapat terlihat bahwa baik buruknya budaya keselamatan dipengaruhi oleh budaya organisasi. Sikap budaya keselamatan adalah cara pandang perawat pelaksana terhadap budaya keselmatan. Adanya alat ukur yang akan menilai sikap memungkinkan menghasilkan sikap negatif dan positif. Sikap negatif diartikan sebagai rendahnya evaluasi terhadap objek yang ada yang akan mencerminkan perilaku seseorang dan sebaliknya sikap positif merupakan tanggapan dan pandangan perawat pelaksana terhadap program budaya keselamatan (Budhihardjo, 2014).

Pembahasan :

Menurut Gibson variabel organisasi, mempunyai efek tidak langsung terhadap perilaku dan kinerja individu.7 Salah satu dari variabel organisasi adalah budaya organisasi itu sendiri. Budaya yang kuat membantu kinerja organisasi karena menciptakan suatu tingkat motivasi yang luar biasa dari dalam diri pegawai. Nilainilai dan perilaku yang dianut bersama membuat orang merasa nyaman dalam bekerja. Budaya keselamatan pasien yang ada dirumah sakit memiliki hubungan langsung terhadap pelaksanaan pelayanan yang bertujuan untuk menjamin keselamatan pasien. Kemudian budaya keselamatan pasien itu sendiri juga dipengaruhi olek kepemimpinan transformasional dalam organisasi tersebut.9 Ditinjau dari aspekaspek pembentuk budaya keselamatan pasien pada dasarnya hampir seluruh aspek terbilang telah diterapkan dengan baik. Hanya saja berbeda untuk penyerahan dan pemindahan pasien, staf yang adekuat, harapan dan tindakan supervisor/manajer dalam mepromosikan keselamatan pasien, serta respon tidak menyalahkan. Dalam melaksanakan asuhan keperawatan kepada pasien, perawat akan selalu membutuhkan bantuan dari perawat maupun tenaga kesehatan yang lainnya, korelasi antara unit kerja/kerjasama dengan penerapan patient safety adalah bermakna, kerjasama yang dilakukan didalam unit kerja masingmasing. Kerjasama yang baik tentu akan menghasilkan penerapan budaya keselamatan pasien yang baik. Penerapan budaya keselamatan pasien yang adekuat harus ditunjang oleh seluruh unit di rumah sakit tersebut. Unit-unit ini diharapkan dapat bekerja sama membentuk suatu sistem kerja sehingga proses pelayanan kesehatan dapat berjalan dengan optimal. Terwujudnya pelayanan kesehatan yang bermutu dan aman tergantung pada kokohnya sistem yang dibangun dari unit-unit yang ada di rumah sakit. Ada 
hubungan komunikasi terhadap budaya keselamatan pasien, hasil penelitian ditemukan bahwa masih minimnya feedback yang diberikan tentang perubahan yang dilakukan berdasarkan laporan insiden kemudian staf mengemukakan bahwa tidak dapat berbicara dengan bebas apabila mereka melihat suatu hal yang dapat berdampak negatif pada perawatan pasien. Kegagalan komunikasi paling tinggi ditemui pada komunikasi lisan.19 Keselamatan pasien dapat ditingkatkan melalui komunikasi efektif, tepat waktu, akurat, lengkap, dan jelas, komunikasi antara pemberi pelayanan harus ditingkatkan, komunikasi dalam pelayanan Kesehatan terjalin antara semua tim yang terlibat dalam pengobatan dan perawatan pasien, kondisi kesehatan pasien yang menyangkut status kesehatan pasien yang membahayakan dan hasil pemeriksaan penunjang harus dikomunikasikan dengan lengkap dan tepat waktu. Komunikasi yang baik antar petugas medis dengan pasien akan memberikan dampak yang positif terhadap mutu pelayanan kesehatan di suatu rumah sakit serta dimungkinkan menurunkan kesalahpahaman apabila terjadi kecelakaan, kelalaian dan ataupun malpraktik.17 Pola komunikasi berpengaruh terhadap budaya keselamatan pasien, pola komunikasi menggambarkan saling percaya dan terbuka (communication founded on mutual trust and openness); alir dan proses informasi yang baik (good information flow and processing) akan meningkatkan budaya keselamatan pasien. Staf yang adekuat juga menjadi faktor penentu dalam penerapan budaya keselamatan pasien. Kurangnya jumlah maupun kualitas tenaga perawatan berdampak pada tingginya beban kerja perawat yang merupakan faktor kontribusi terbesar sebagai penyebab human error dalam pelayanan keperawatan. Oleh karena itu, sangat direkomendasikan untuk meningkatkan jumlah staf yang adekuat untuk meningkatkan keselamatan pasien. Rumah sakit dengan staf keperawatan yang tidak memadai sangat berisiko untuk terjadi kesalahan yang berujung kepada terjadinya hal yang tidak diinginkan. Menurut Rahmawaty, faktor individu atau petugas sangat berpengaruh terhadap budaya keselamatan pasien ialah perasaan takut disalahkan. Adanya budaya menyalahkan di lingkungan rumah sakit mengakibatkan petugas cenderung tidak melaporkan kejadian kesalahan pelayanan karena takut dimarahi, tidak mau temannya dimarahi, dan karena sungkan terhadap rekan kerja yang lebih senior.(13) Sementara itu menurut Julliet, respon tidak meghukum merupakan dimensi penting yang dapat dilaksanakan ketika 
menghindari sikap menyalahkan orang lain, mulai membuka komunikasi dan mengembangkan sistem pemberian penghargaan untuk pelaporan praktik yang tidak aman. Budaya keselamatan menurut Pronovost, adalah karakteristik budaya keselamatan pasien yang proaktif, meliputi komitmen dari pimpinan untuk mendiskusikan dan belajar dari kesalahan, mendorong dan mempraktikkan kerja sama tim, membuat sistem pelaporan terkait KTD, KNC dan sentinel serta memberikan penghargaan bagi staf yang menjalankan program keselamatan pasien dengan baik. (18) Budaya keselamatan pasien postif meliputi komunikasi yang didasarkan pada kepercayaan dan terbuka, proses dan alur informasi yang baik, persepsi bersama tentang arti penting keselamatan pasien, perhatian pada pengenalan pentingnya kesalahan. Budaya keselamatan lainnya yakni adanya alat ukur yang meyakinkan tentang keselamatan pasien, identifikasi proaktif terhadap ancaman laten keselamatan pasien, pembelajaran organisasi, komitmen pemimpin dan para staf serta pendekatan tidak menyalahkan terhadap pelaporan kejadian. Budaya keselamatan pasien negatif meliputi tingkat karir yang curam antar staf medis dengan staf lain, hubungan tim kerja yang renggang, dan keengganan mengakui kesalahan. Gibson menyatakan budaya keselamatan pasien postif akan meningkatkan produktivitas, sedangkan budaya keselamatan pasien negatif akan merusak keefektifan dari suatu tim dan menimbulkan efek desain organisasi yang tidak baik.(19) Dalam budaya keselamatan pasien baik pemimpin organisasi, pihak manajemen dan staf perlu belajar secara terus menerus guna meningkatkan kinerja organisasi dan menunjukkan keberhasilan upaya dalam peningkatan dan perbaikan budaya keselamatan pasien. Keselamatan pasien merupakan tanggung jawab semua pihak yang berkaitan dengan pemberi pelayanan kesehatan, stakeholder mempunyai tanggung jawab memastikan tidak ada tindakan yang membahayakan pasien.23 Masyarakat, pasien, dokter, tenaga perawat, tenaga kesehatan, peneliti, kalangan professional, lembaga akreditasi rumah sakit dan pemerintah memiliki tanggung jawab bersama dalam upaya keselamatan pasien.24 Keselamatan pasien menjadi prioritas utama dalam layanan kesehatan dan merupakan langkah kritis pertama untuk memperbaiki kualitas pelayanan serta berkaitan dengan mutu dan citra rumah sakit. Dalam menciptakan budaya keselamatan pasien adalah pelaporan kejadian insiden/kondisi yang tidak diharapkan serta adanya sistem umpan 
balik, kondisi ini belum membudaya di instansi-instansi pelayanan kesehatan karena ada faktor ketakutan atau kekhawatiran atau bahkan menganggap insiden merupakan aib petugas kesehatan yang harus ditutupi. Budaya belajar dari kesalahan dan tidak melakukan pelebelan/blaming terhadap petugas yang melakukan kesalahan harus ditunjukan oleh pimpinan.29 Berdasarkan penelitian ditemukan bahwa budaya pelaporan sangat lemah, diakibatkan takut disalahkan, pelaporan merupakan unsur penting dari keselamatan pasien.30 Informasi yang adekuat akan digunakan sebagai data untuk proses pembelajaran dalam meningkatkan upaya keselamatan pasien. Ada hubungan pendidikan dan pelatihan terhadap budaya keselamatan pasien, pendidikan dan pelatihan yang masih kurang baik masih cukup besar hal tersebut dikarenakan belum semua responden tersentuh untuk diikutkan pelatihan. Apabila karyawan mempunyai pengetahuan dan ketrampilan yang baik dalam keselamatan pasien maka akan meningkatkan budaya keselamatan pasien, penting seluruh karyawan harus mempunyai persepsi yang sama tentang pentingnya keamanan/safety dalam melakukan pelayanan (shared perceptions of the importance of safety), dapat disimpulkan bahwa pendidikan dan pelatihan tentang keselamatan pasien berpengaruh secara positif terhadap budaya keselamatan pasien. 5 Terdapat peningkatan bermakna sebelum dan sesudah pelatihan pada keterampilan perawat klinik dalam keselamatan pasien. Sikap komitmen dengan motivasi tinggi sangat dibutuhkan perawat dalam memberikan pelayanan kesehatan kepada pasien. Dengan sikap tersebut perawat akan bekerja secara profesional dalam memberikan asuhan keperawatan yang sesuai standar dan sebagai upaya meningkatkan kualitas pelayanan keperawatan, sehingga dapat memberikan kepuasan kepada pasien dan perawat itu sendiri, dimana pegawai yang memiliki komitmen tinggi akan menunjukkan sikap kerja yang penuh perhatian. dan bertanggung jawab atas tugasnya dan menunjukkan kesetiaan kepada organisasinya. Program pengembangan staf melalui pelatihan dan pendidikan merupakan program yang efektif untuk meningkatakan produktifitas bagi perawat, dukungan yang adekuat dalam bentuk pelatihan profesional dan pengembangan pengetahuan merupakan salah satu upaya untuk menciptakan lingkungan kerja yang positif bagi perawat agar asuhan yang aman dapat diberikan. 


\section{Daftar Pustaka :}

1. Yennike Tri Herawati (2015). Budaya Keselamatan Pasien di Ruang Rawat Inap Rs. X Kabupaten Jember. Volume 11 Nomor 1 Maret 2015.

2. Iriyanto Pagala, Zahroh Shaluhiyah, Baju Widjasena (2017). Perilaku Kepatuhan Perawat Melaksanakan SOP Terhadap Kejadian Keselamatan Pasien di Rumah Sakit X Kendari. Vol 12 nomor 1.

3. Afrisya Iriviranty (2014) Analisis Budaya Organisasi dan Budaya Keselamatan Pasien Sebagai Langkah Pengembangan Keselamatan Pasien di RSIA Budi Kemuliaan Tahun 2014. Volume 1 Nomor 3

4. Basok Buhari (2019). Budaya Keselamatan Pasien Rumah Sakit Pemerintah dan Rumah Sakit Swasta di Kota Jambi. Volume 3, Nomor 1, Februari 2019.

5. Nur Syarianingsih Syam (2017). Implementasi Budaya Keselamatan Pasien oleh Perawat di Rumah Sakit Ibnu Sina Makassar. Volume 11, Issue 2, September 2017, pp. $169 \sim 174$.

6. Yulia Yasmi , Hasbullah Thabrany (2015). Faktor-Faktor yang Berhubungan dengan Budaya Keselamatan Pasien di Rumah Sakit Karya Bhakti Pratiwi Bogor Tahun 2015. Volume 4 Nomor 2 (98-109)

7. Agustina Pujilestari, Alimin Maidin, Rini Anggraeni (2014). BUDAYA Keselamatan Pasien di Instalasi Rawat Inap RSUP DR. Wahidin Sudirohusodo Kota Makassar. , hal 57-64

8. Yeni Yarnita (2018). Analisis Hubungan Sikap Perawat Dengan Budaya Keselamatan Pasisen di Ruang Rawat Inap RSUD Arifin Achmad Provinsi Riau. Vol. 8 No. 2, April 2018

9. Tantri Arini (2018). Tesis Budaya Keselamatan Pasien Berbasis Pemberdayaan Struktural Dengan kepuasan Kerja Perawat. Universitas Airlangga Surabaya.

10. KHeriyati, Muhammad Fauzar AlHijrah, Masniati (2019) Budaya Keselamatan 
Pasien Rumah Sakit Umum Daerah Majene. Vol. 2 No. 3. (192-205) 